\title{
Surgical Management of Inferior Vena Cava Tumor Thrombus in Patients with Renal Cell Carcinoma
}

\author{
Böbrek Hücreli Karsinom Hastalarında Inferior Vena Kava Tümör Trombüsünün Cerrahi Tedavisi
}

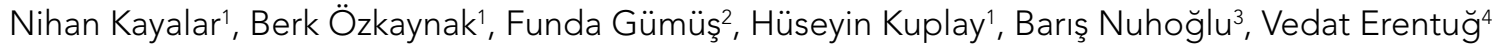 \\ ${ }^{1}$ Clinic of Cardiovascular Surgery, Bağcılar Training and Research Hospital, İstanbul, Turkey \\ ${ }^{2}$ Clinic of Anaesthesiology and Reanimation, Bağcılar Training and Research Hospital, ìstanbul, Turkey \\ ${ }^{3}$ Department of Urology, Faculty of Medicine, Erzincan University, Erzincan, Turkey \\ ${ }^{4}$ Department of Cardiovascular Surgery, Faculty of Medicine, Erzincan University, Erzincan, Turkey
}

\begin{abstract}
Renal cell carcinoma (RCC) is associated with a biological propensity for vascular invasion with extension of the tumor to the renal vein or inferior vena cava and total resection of the renal tumor and IVC tumor thrombus is considered the optimal therapy when no distant metastases are present. The surgical approach to a specific patient with RCC and IVC tumor thrombus should be selected according to the level of the tumor thrombus and the characteristics of the primary renal tumor such as size, location, regional lymphadenopathy and aberrant vascular anatomy. The surgical management of RCC and IVC tumour thrombus requires the commitment of a multidisciplinary surgical team particularly for a higher (level III and IV) tumor thrombus. Preoperative imaging is very important for the surgical planning and management. An extended chevron incision with or without a sternotomy provides excellent surgical exposure. Level 0, level I and most level II tumors can be removed using straightforward occluding maneuvers, while maintaining control of the caval thrombus and the contralateral renal vein. Vascular bypass can frequently be required for the safe and complete resection of level III tumor thrombus. The resection of level IV tumors is generally performed with the use of cardiopulmonary bypass and circulatory arrest. In this review, these surgical aspects and treatment of IVC tumor extension in patients with RCC will be summarized, hoping to provide a clear and comprehensive guideline for both urology and cardiovascular specialists. (JAREM 2013; 3: 47-52)
\end{abstract}

Key Words: Renal cell carcinoma, inferior vena cava, tumor thrombus

\section{ÖZET}

Böbrek hücreli karsinom (BHK), renal ven ve inferior vena kavaya (IVK) uzanarak vasküler invazyon yapma eğilimi olan bir tümördür. Böbrek tümörünün ve IVK tümör trombüsünün total rezeksiyonu uzak metastaz yok ise optimal tedavi olarak kabul edilmektedir. Cerrahi tedavinin hastaya tam iyileşme sağlamasının mümkün olmadığı durumlarda dahi, tümör trombüsünün rezeke edilmesi semptomatik hastalarda yaşam kalitesini iyileştirebilir. BHK ve IVK tümör trombüsü olan hastalara cerrahi yaklaşım tümör trombüsünün seviyesine ve primer böbrek tümörünün boyut, konum, bölgesel lenfadenopati ve anormal vasküler anatomi varlığı gibi özelliklerine bağlıdır. Bu hastaların cerrahi tedavisi, özellikle yüksek seviyede (Seviye III ve IV) tümör trombüsü varlığında multidisipliner bir cerrahi takım çalışmasını gerektirir. Operasyon öncesi görüntüleme cerrahi planlama ve tedavinin seçimi için çok önemlidir. MRI görüntüleme tümör trombusünün uzanımını, IVK oklüzyonunun derecesini, vasküler anomalilerin varlığını ve infrarenal seviyede yumuşak trombüs olup olmadığını göstermede en duyarlı teknik olarak kullanılmaktadır. Cerrahi yaklaşım için uzatılmış Chevron insizyonu ve gereğinde sternotomi kullanılmakta ve iyi bir cerrahi alan görünümü sağlanmaktadır. Seviye 0, I ve II tümörlerin rezeksiyonu, kaval trombüsün ve kontralateral böbrek veninin kontrolü sağlandıktan sonra oklüzyon manevraları kullanılarak rahatlıkla yapılabilmektedir. Seviye III tümörler, karaciğerin arkasındaki lokalizasyonları nedeniyle cerrahi olarak yaklaşımı en zor olan tümörlerdir. Seviye III tümör trombüsünün rezeksiyonunun güvenli ve tam olarak yapılabilmesi için sıklıkla vasküler bypass metodlarının kullanılması gereklidir. IVK oklüzyonu sonrası kalbe venöz dönüşün azalmasıyla birlikte hipotansiyon gelişen veya kollateral venlerden çok miktarda kanama gözlenen hastalarda bu teknikler kullanılır. Vasküler bypass için klasik olarak kardiyopulmoner bypass ve derin sirkülatuar arest kullanılmakta iken, günümüzde daha çok santrifujal bir pompa kullanılarak venö-venöz bypass (IVK ve sağ atriyum kanülasyonu ile) uygulanmaktadır. Minimal invaziv ve perkutan bypass teknikleri de bildirilmiştir. Seviye IV tümörlerinin rezeksiyonu için genellikle kardiyopulmoner bypass ve total sirkulatuar arrest kullanılması gereklidir. Ancak, sadece intraabdominal yaklaşımla seviye IV tümör trombüs rezeksiyonu da tarif edilmiştir. Trombüs seviyesi ne olursa olsun, IVK duvarının invazyonundan şüphe ediliyorsa, vena kavanın parsiyel veya total rezeksiyonu gereklidir. Rezeksiyon yapılmaması veya küçük bir alanda yapılması durumunda primer venorafi ile IVK onarılabilir ve açıklık oranı vena kava çapın geniş olması nedeniyle yüksektir. IVK'nin \%50'sinden fazlası rezeke edildiyse IVK rekonstrüksiyonu gereklidir. IVK rekonstrüksiyonu otolog perikard ve sığır perikardı gibi biyolojik materyaller kullanılarak yapılabileceği gibi politetrafloroetilen yama veya tüp greft ile de yapılabilir. Alternatif olarak, total olarak oklüde olmuş bir IVK, yeterli kollateral varlığında primer olarak güvenli bir şekilde bağlanabilir. Bu derlemede böbrek hücreli tümor ve IVK tümör trombüsü olan hastalara cerrahi yaklaşım ve teknikler özetlenecektir. Bu derlemenin Üroloji ve Kalp Damar Cerrahisi uzmanları için açık ve ayrıntılı bir rehber oluşturacağı inancındayız. (JAREM 2013; 3: 47-52)

Anahtar Sözcükler: Böbrek hücreli karsinom, inferior vena kava, tümör trombüsü

\section{INTRODUCTION}

Renal cell carcinoma (RCC) is associated with a biological propensity for vascular invasion with extension of the tumor to the renal vein or inferior vena cava (IVC) in approximately $5 \%$ to $10 \%$ of cases $(1,2)$, and into the right atrium in about $1 \%$ of cases (2). Total resection of the renal tumor and IVC tumor thrombus is considered the optimal therapy when no distant metastases are present $(1,3)$. Even if the surgery does not cure the patient,
Received Date / Geliş Tarihi: 21.08.2012Ａccepted Date / Kabul Tarihi: 27.08.2013 C) Telif Hakkı 2013 AVES Yayıncllk Ltd. Şti. Makale metnine www.jarem.org web sayfasından ulaşılabilir. C Copyright 2013 by AVES Yayınclik Ltd. Available online at www.jarem.org 
removal of the tumor thrombus may provide a better quality of life in symptomatic patients (i.e. intractable edema, cardiac dysfunction, abdominal pain, hematuria).

The surgical approach to a specific patient with RCC and IVC tumor thrombus should be selected according to the level of the tumour thrombus and the characteristics of the primary renal tumor such as size, location, regional lymphadenopathy and aberrant vascular anatomy. It is of utmost importance to determine whether the tumor thrombus is infrahepatic, intrahepatic, or suprahepatic, since this will ultimately determine which surgical approach, technique of IVC control, and necessity of vascular bypass may be needed. Therefore, it is imperative that accurate preoperative imaging be obtained. The presence of an IVC tumor thrombus, with its associated risks of venous congestion and distal embolism, adds immediacy to the management of such patients. In addition, IVC occlusion results in development of collaterals and parasitic vasculature which increase the technical difficulty of nephrectomy. All these factors necessitate good preoperative planning and cooperation of the urology and car- diovascular teams throughout the management process of these patients. In this review, we will focus on the surgical approach and treatment of IVC tumor extension in patients with RCC, hoping to provide a clear and comprehensive guideline for both urology and cardiovascular specialists.

\section{Staging}

As shown in Table 1 pertaining to the 2010 American Joint Committee on Cancer (AJCC) clinical staging system for RCC, the tumor is staged as "T3" when it has grown into major veins or perinephric tissue (4). A tumour extending into the renal vein or its segmental branches is staged as T3a. A tumour extending into the IVC below the level of the diaphragm is staged as T3b. A supradiaphragmatic tumour or tumour with vena cava wall invasion is staged as T3c. Besides TNM staging, several different staging strategies have been proposed for patients with RCC and venous tumor thrombus (5-9). A tumour thrombus found in the renal vein extending $<2 \mathrm{~cm}$ within the IVC is staged as a level I thrombus in the Neves and Novick systems $(5,6)$. Infrahepatic thrombus

Table 1. 2010 AJCC TNM clinical staging system for renal cell carcinoma

\section{Tumor status}

- TX: The primary tumor cannot be evaluated.

- T0: There is no evidence of a primary tumor in the kidney(s).

- T1: The tumor is found only in the kidney and is 7 centimeters $(\mathrm{cm})$ or smaller in size at its largest region. There has been much discussion among doctors whether this classification should only include a tumor $5 \mathrm{~cm}$ and under.

- T1a: The tumor is found only in the kidney and is $4 \mathrm{~cm}$ or smaller in size at its largest region.

- T1b: The tumor is found only in the kidney and is between $4 \mathrm{~cm}$ and $7 \mathrm{~cm}$ at its largest region.

- T2: The tumor is found only in the kidney and is larger than $7 \mathrm{~cm}$ in size at its largest region.

- T2a: The tumor is only in the kidney and is more than $7 \mathrm{~cm}$ but $10 \mathrm{~cm}$ or less at its largest region.

- T2b: The tumor is only in the kidney and is more than $10 \mathrm{~cm}$ at its largest region.

- T3: The tumor has grown into major veins or perinephric tissue (connective, fatty tissue around the kidneys). It has not grown into the adrenal gland (gland on top of each kidney that produces hormones and adrenaline to help control heart rate, blood pressure, and other body functions) on the same side of the body as the tumor, and it has not spread beyond Gerota's fascia (an envelope of tissue that surrounds the kidney).

- T3a: The tumor has spread to the large vein leading out of the kidney, called the renal vein, or the muscles of the vein, or it has spread to the fat surrounding the kidney and/or the fat inside the kidney. The tumor has not grown beyond Gerota's fascia.

- T3b: The tumor has grown into the large vein leading out of the heart, called the vena cava, below the muscle known as the diaphragm under the lungs that helps breathing.

- T3c: The tumor has spread to the vena cava above the diaphragm or the walls of the vena cava.

- T4: The tumor has spread to areas beyond Gerota's fascia and extends into the adrenal gland on the same side of the body as the tumor.

Nodal status. The ' $\mathrm{N}$ ' in the TNM staging system stands for lymph nodes. Lymph nodes near the kidneys are called regional lymph nodes. Lymph nodes in other parts of the body are called distant lymph nodes.

- NX: The regional lymph nodes cannot be evaluated.

- NO: The cancer has not spread to the regional lymph nodes.

- N1: The cancer has spread to regional lymph nodes.

Distant metastasis. The ' $\mathrm{M}$ ' in the TNM system indicates whether the cancer has spread to other parts of the body. Common areas where kidney cancer may spread include the bones, liver, lungs, brain, and distant lymph nodes.

- M0: The disease has not metastasized.

- M1: The cancer has spread to other parts of the body beyond the kidney area. 
Table 2. Classification of patients with renal cell carcinoma according to tumor thrombus level

\begin{tabular}{|l|l|}
$\begin{array}{l}\text { Tumor thrombus } \\
\text { level }\end{array}$ & Definition \\
\hline O & $\begin{array}{l}\text { Thrombus limited to the renal vein; } \\
\text { detected clinically or during assessment } \\
\text { of the pathological specimen }\end{array}$ \\
\hline I & $\begin{array}{l}\text { Thrombus extending into IVC, }<2 \mathrm{~cm} \text { above } \\
\text { renal vein }\end{array}$ \\
\hline II & $\begin{array}{l}\text { Thrombus extending }>2 \mathrm{~cm} \text { above the renal } \\
\text { vein but below the hepatic veins }\end{array}$ \\
\hline III & $\begin{array}{l}\text { Thrombus at the level or above the hepatic } \\
\text { veins, but below the diaphragm }\end{array}$ \\
\hline IV & Thrombus extending above the diaphragm \\
\hline IVC: inferior vena cava
\end{tabular}

is staged as a level II thrombus. An intrahepatic IVC thrombus below the diaphragm is staged as level III and an IVC tumour thrombus extending above the diaphragm is staged as level IV $(5,6)$. The Hinman staging system includes three respective levels of IVC tumour thrombus. Infrahepatic thrombus is staged as level I. Thrombus above the hepatic veins but below the diaphragm is staged as level II. Thrombus at or above the level of the diaphragm is staged as III (7). The classification scheme proposed by Montie et al. (8) listed in Table 2, is also specific for the level of IVC tumor thrombus and, as the level of involvement of the vena cava has implications for the surgical approach, it can be used for clinical staging.

\section{Preoperative Assessment and Imaging}

Most patients with an IVC tumor thrombus are symptomatic at the time of presentation (9). Local tumor growth may cause symptoms such as flank pain or hematuria and other symptoms such as fatigue, weight loss, or a paraneoplastic syndrome can be constitutional in nature. The thrombus-related occlusion of the IVC may result in lower extremity edema, new onset varicocele or, in the case of thrombus dislodgement, pulmonary embolus. On the other hand, symptoms directly attributable to the tumor thrombus may be absent even in the presence of total IVC occlusion, because venous collateralization occurs through the azygos and lumbar systems. Hence, the presence of an IVC thrombus is often first detected by radiologic imaging which is a crucial step in the management of RCC with IVC thrombus by evaluating the proximal extent, volume of the tumour thrombus, and potential of caval wall invasion, thus providing the information necessary to determine the best surgical approach for a given patient.

IVC extension of a tumor thrombus can be successfully identified by transabdominal and transesophageal sonography, CT, MR imaging, and inferior vena cavography. Historically, vena cavography was used for the detection and evaluation of a tumour thrombus within the IVC (10). However, a venacavagram cannot sufficiently delineate the cephalad extent of the thrombus, particularly in patients with vena cava occlusion and identification of the relation of the thrombus to the hepatic vein is sometimes not clear on venacavography (11). Moreover, this procedure is limited by its invasive nature and risks of complications imposed upon patients (12). Well-performed cross-sectional imaging studies are paramount to the appropriate assessment of these patients. In addition to imaging the primary renal tumor, they facilitate the detection of any lymphadenopathy and/or intra-abdominal metastasis. Although CT is usually the initial imaging modality that leads to the diagnosis of these tumors, MRI has been established to determine the extent of tumor thrombus, degree of IVC occlusion, and presence of venous anomalies and/or bland thrombus in the infrarenal IVC $(11,13)$. The sensitivity of MR imaging (90\%) for detecting an IVC thrombus that resulted from renal cell carcinoma was greater than that of either CT (79\%) or conventional sonography (68\%) (14). In addition, if a repeat imaging study is required, exposure of the patient to iodinated contrast is minimized by using MRI. However, with the advent of the multidetector CT (MDCT), CT may soon replace MRI as the imaging method of choice. Recent studies have shown that MDCT has a sensitivity of $93 \%$ and a specificity of $80 \%$ in delineating the extent of the tumor thrombus $(10,15)$ and the study by Nazim et al. (16) concluded that MDCT has $97 \%$ specificity for detecting tumour thrombus in the renal vein and IVC.

The progression rate for IVC tumor thrombi has been reported to be rapid, exceeding the reported rates for primary renal tumors (17); therefore, up-to-date imaging studies must be obtained before proceeding with surgical resection. It is recommended that the longest interval from CT and/or MRI imaging of the renal tumor and IVC thrombus up to the day of surgery should be no longer than 30 days (12). Preoperative ultrasonography can be performed to quickly assess a caval thrombus. If a tumor thrombus is shown to extend into the right atrium, or if pulmonary emboli are suspected, further preoperative assessments, including transesophageal echocardiography (TEE) or CT angiography of the pulmonary vasculature, might be considered. The staging work-up is completed with chest imaging and blood tests, unless the test results or symptoms dictate further imaging. TEE is also routinely used intraoperatively by some surgeons to monitor the cephalad extent and location of the thrombus, as well as the adequacy of retraction and resection within the IVC (18). If the surgery warrants the use of cardiopulmonary bypass (CPBP) in cases of a higher level thrombus (III or IV), a coronary angiography should be performed.

Patients with evidence of bland thrombus on preoperative imaging are given systemic anticoagulation therapy to prevent propagation of the bland thrombus. The use of intravenous heparin permits close monitoring of anticoagulation parameters, as well as rapid withdrawal of anticoagulation therapy immediately before surgery. Some institutions favor angioembolization of the kidney before surgery, which has been suggested to decrease intraoperative blood loss, facilitate a direct route to the renal hilum, and result in partial regression of the tumor thrombus (19). Nevertheless, findings to support the use of this technique are currently scarce, and many surgeons do not routinely practice angioembolization before nephrectomy $(12,17)$. Performing surgery in a cardiovascular operating suite has advantages of ease of going on to cardiopulmonary bypass if necessary, having a cardiovascular surgical team ready together with an anesthesics team familiar with cardiovascular techniques and facilitating intraoperative TEE if necessary. 


\section{Surgical Management}

The goal of surgery for patients with RCC involving the IVC is to resect the entire tumor burden. In addition to nephrectomy with caval thrombectomy, caval resection and/or reconstruction, resection of retroperitoneal lymph nodes, or metastasectomy might also be required. The surgery in cases of RCC with IVC tumor thrombus should be thought of as a procedure on the IVC rather than an operation on the kidney and the surgical approach used depends on the level of thrombus and the extent of thrombus propagation throughout the IVC, as well as whether caval clamping is necessary. Approximately two-thirds of the overall venous return is from the IVC and a third from the superior vena cava. A third of the IVC return is from its inferior aspect, a third from the renal veins and the final third from the hepatic venous outflow. This distribution can be altered when extensive collateralization occurs in the setting of IVC obstruction and develops along the ascending lumbar veins and azygos system (17). If the IVC thrombus is of low volume and obstruction is incomplete, caval clamping can result in profound hypotension and the need for augmentation of venous return (i.e. veno-venous bypass) will arise. Therefore, one of the most pivotal surgical considerations is determining whether the tumor thrombus is infrahepatic, intrahepatic, or suprahepatic.

Surgical approach can be through an anterior subcostal or chevron abdominal incision when the likelihood of the necessity to perform a bypass is low. Subcostal incisions offer excellent exposure and allow the extension of the incision to the contralateral side or cephalad in the midline if a sternotomy is needed. Nevertheless, this type of approach can result in considerable postoperative pain. If a cardiopulmonary bypass (CPB) is clearly planned before surgery, a midline abdominal incision with extension to sternotomy is more favorable. A thoracoabdominal incision may provide better exposure for large tumours of the upper renal pole. However, thoracic complications such as risk of pneumothorax, phrenic nerve injury, severe postoperative pain, increased risk of atelectasis and pneumonia, and necessity for a postoperative chest tube may be associated with this approach. A minimal access technique, involving cannulation of the right subclavian artery and of the right atrium through a small right parasternal incision, has been described as an alternative to the median sternotomy for establishing cardiopulmonary bypass with hypothermic circulatory arrest (20). This method was reported to be associated with decreased operative times, duration of hospital stays, and requirements for mechanical ventilation and transfusion (20). A percutaneous veno-venous bypass technique via femoral and jugular veins and femoral artery has been described for patients with an IVC tumor thrombus extending above the hepatic veins but not into the right atrium with similar advantages (21). Although laparoscopic approaches to radical nephrectomy in patients with venal caval tumor thrombus have been described (22), these methods are currently only applied in selected cases with low-level thrombi.

After the exposure of the kidney and anterior surface of the great vessels, surgeons generally prefer ligating the renal artery first ( 2 , $12,17)$. This has the advantage of reducing bleeding from venous collaterals and can actually cause the tumor thrombus to retract. Thrombectomy of the vena-caval tumor and nephrectomy follow this step.

\section{Level 0, Level I and Level II thrombus}

Level 0 or I tumors can be treated in a similar fashion, since level 1 thrombi minimally extend into the IVC, and can frequently be manipulated into the renal vein. Level 0 or 1 tumors can usually be encompassed within an appropriately shaped vascular sideclamp without occluding IVC flow. The ostium of the renal vein is circumscribed, thus facilitating removal of the tumor thrombus together with removal of the kidney and the renal vein. The caval defect is then oversewn using a continuous 4-0 or, sometimes if the wall is thin, a 5/0 polypropylene suture. Thus, level 0 , level 1 and most level II tumors can be removed using straightforward occluding maneuvers, while maintaining control of the caval thrombus and the contralateral renal vein.

Level II tumors often necessitate more extensive mobilization of the IVC. Ligation and division of the lumbar veins in order to gain control of the IVC segments proximal and distal to the tumor thrombus may be necessary. This is also important to prevent significant blood loss. In most cases, vascular bypass is not necessary during surgery for level II tumors. Once adequate exposure has been obtained, the IVC is occluded by placing vascular and vein clamps or tourniquets, in the order from suprarenal IVC above the thrombus, contralateral renal vein and the infrarenal IVC to prevent embolization. It may be necessary to ligate and divide the accessory hepatic veins from the caudate lobe of the liver to the IVC to facilitate cephalad exposure of the IVC and clamp placement. At this stage, it is important to monitor hemodynamic parameters closely and have rapid resuscitative measures, including blood products, ready. A test clamping of IVC for a brief period of time before conducting the cavotomy and thrombectomy may be helpful to assess whether additional resuscitative and/or transfusion measures will be necessary. Afterwards, the IVC is opened from the renal ostium cephalad over the tumor. The thrombus is gently dissected away from the wall of the IVC, and the ostium of the renal vein is circumscribed and removed with the kidney as for level I tumors. Caval resection or biopsy may be indicated to ensure negative surgical margins. The cavotomy is oversewn using a continuous $4-0$ or 5/0 polypropylene suture.

\section{Level III and Level IV thrombus}

Level III tumors are difficult to identify accurately because of their retrohepatic nature and the proximity of the confluence of the hepatic veins to the right atrium. They are also difficult to access due to the difficulty of IVC exposure at this level (17). In many cases of level III tumor, resection can be performed entirely intraabdominally, as described for level II tumors $(17,23)$. It might be necessary to use liver transplant techniques, such as mobilization of the right lobe of the liver by dividing the coronary and triangular ligaments, in order to expose the retrohepatic and suprahepatic IVC and to permit clamping above the cephalad extent of the thrombus (17). The short hepatic veins draining the right and caudate lobe are suture ligated on the IVC side. This method allows milking of the tumor thrombus below the hepatic venous confluence, permitting clamping of the IVC below the entry of the hepatic veins and thereby avoiding liver congestion (24). If this technique is not possible, the Pringle maneuver is commonly used to control hepatic inflow by manual compression or vascular clamp occlusion. It should be kept in mind that, if suprarenal 
IVC vascular control above the proximal extent of the tumour thrombus cannot be gained with retrohepatic IVC mobilisation, then a midline sternotomy will be required to control the supradiaphragmatic IVC.

Vascular bypass can frequently be required for the safe and complete resection of level III tumors. Vascular bypass is particularly indicated in cases where the patient is thought not to be able to tolerate cross-clamping and the subsequent decrease in venous return without significant hypotension, and in cases where cross-clamping is noted to result in extensive haemorrhage from venous collaterals. There are several options for vascular bypass, once the need is established. Traditionally, vascular bypass for tumor thrombus cases has consisted of cardiopulmonary bypass with hypothermic $\left(18^{\circ} \mathrm{C}\right)$ circulatory arrest $(2,12,17)$. This technique provides a relatively bloodless field for cavotomy and thrombectomy, but the cooling and rewarming process, plus the need for anticoagulation, increases operative times, anesthesia times, and the risk of postoperative coagulopathy. Veno-venous vascular bypass can be used for most cases of level III tumor thrombus, as well as for the few level II thrombi that require bypass for resection $(2,17)$. This technique has the advantage of avoiding hypotension during vena-cava occlusion and thus allows performance of an unhurried inspection and repair of the IVC. Veno-venous bypass is commenced by placing a venous cannula of appropriate size (mostly $20 \mathrm{~F}$ ) through a purse-string suture in the IVC, well below the caudal extent of the thrombus. An 8-14 F venous cannula is then introduced into the right atrium or right brachial vein to provide venous return. Both cannulae are connected to a centrifugal pump via a modified heparin-bonded Gott aneurysm shunt, and the bypass is initiated.

The resection of level IV tumors is generally performed with the use of cardiopulmonary bypass and circulatory arrest. It may be possible to use veno-venous bypass for level IV tumors, particularly when the TEE demonstrates a freefloating thrombus that can easily be maneuvered below the diaphragm (17). Alternatively, a completely intra-abdominal approach has been described for level IV tumors by completely mobilizing liver with division of the right and left triangular ligaments as well as the right inferior and superior coronary ligaments (25). With this technique, the central diaphragm tendon is dissected until the supradiaphragmatic intrapericardial IVC can be visualized and caval thrombectomy is performed clamping the right atrium without entering the chest.

Regardless of thrombus level, suspected invasion of the IVC wall necessitates partial or total resection of the IVC to achieve complete removal of tumor. Primary venorrhaphy (without resection) of the IVC has been shown to have a high patency rate (> 90\%) due to its large venous wall diameter (26). In general, IVC reconstruction with grafting is indicated if $>50 \%$ of the caval wall must be resected and it can be done by using a biological graft such as autologous pericardium if sternotomy has been performed, or a xenograft such as bovine pericardium, a synthetic patch such as polytetrafluoroethylene or a tube graft. There is currently a lack of data about the patency and efficacy of the different types of IVC resection and reconstruction techniques and materials. Alternatively, a totally occluded IVC can be safely ligated, particularly if collateral venous circulation is suspected based on the chronic- ity of the venous occlusion after a review of the patient's history, preoperative imaging, and/or intraoperative findings.

\section{CONCLUSION}

The mortality and morbidity associated with treatment of RCC and venous tumor thrombus have decreased in parallel with the improvements in preoperative assessment, intraoperative monitoring, and surgical techniques. Radical nephrectomy and tumor thrombectomy should be considered for oncologic and palliative purposes. The surgical management of RCC and IVC tumour thrombus requires the commitment of a multidisciplinary surgical team particularly for a higher (level III and IV) tumour thrombus. Preoperative imaging is very important for the surgical planning and management. The surgical approach should be individualized for each patient and depends on the level of the thrombus and the extent of thrombus propagation throughout the IVC. An extended chevron incision with or without a sternotomy provides excellent surgical exposure. Level 0, level I and most level II tumors can be removed using straightforward occluding maneuvers, while maintaining control of the caval thrombus and the contralateral renal vein. Vascular bypass can frequently be required for the safe and complete resection of level III tumors and is indicated in cases where the patient is thought not able to tolerate cross-clamping and the subsequent decrease in venous return without significant hypotension, and in cases where crossclamping is noted to result in extensive haemorrhage from venous collaterals. The resection of level IV tumors is generally performed with the use of cardiopulmonary bypass and circulatory arrest.

\section{Conflict of Interest}

No conflict of interest was declared by the authors.

Peer-review: Externally peer-reviewed.

\section{Author Contributions}

Concept - V.E., B.N.; Design - V.E., B.N.; Supervision - V.E.; Funding N.K., V.E., Materials - N.K.; Data Collection and/or Processing - N.K., H.K.; Analysis and/or Interpretation - N.K., V.E.; Literature Review - F.G., B.Ö.; Writing - N.K., B.Ö.; Critical Review - V.E., B.N.

\section{Çıkar Çatışmas}

Yazarlar herhangi bir çıkar çatışması bildirmemişlerdir.

Hakem değerlendirmesi: Dış bağımsız.

\section{Yazar Katkıları}

Fikir - V.E., B.N.; Tasarım - V.E., B.N.; Denetleme - V.E.; Kaynaklar - N.K., V.E.; Malzemeler - N.K.; Veri toplanması ve/veya işlemesi - N.K., H.K.; Analiz ve/veya yorum - N.K., V.E.; Literatür taraması - F.G., B.Ö.; Yazıyı yazan - N.K., B.Ö.; Eleştirel İnceleme - V.E., B.N.

\section{REFERENCES}

1. Hatcher PA, Anderson EE, Paulson DF, Carson CC, Robertson JE. Surgical management and prognosis of renal cell carcinoma invading the vena cava. J Urol 1991; 145: 20-3.

2. Boorjian SA, Sengupta S, Blute ML. Renal cell carcinoma: vena caval involvement. BJU Int 2007; 99: 1239-44. [CrossRef]

3. Zisman A, Wieder JA, Pantuck AJ, Chao DH, Dorey F, Said JW, et al. Renal cell carcinoma with tumor thrombus extension: biology, role 
of nephrectomy and response to immunotherapy. J Urol 2003; 169 : 909-16. [CrossRef]

4. Edge SB, Byrd DR, Compton CC, Fritz AG, Greene FL, Trotti A. 7th ed. 2010, New York: Springer-Verlag.

5. Neves RJ, Zincke H. Surgical treatment of renal cancer with vena cava extension. Br J Urol 1987; 59: 390-5. [CrossRef]

6. Novick AC. Stewart's Operative Urology, $2^{\text {nd }}$ ed. Baltimore: Williams\&Wilkins, 1989

7. Hinman F. Atlas of Urologic Surgery. Philadelphia: W.B. Saunders, Co., 1998.

8. Montie JE, el Ammar R, Pontes JE, Medendorp SV, Novick AC, Streem SB, et al. Renal cell carcinoma with inferior vena cava tumor thrombi. Surg Gynecol Obstet 1991; 173: 107-15.

9. Blute ML, Leibovich BC, Lohse CM, Cheville JC, Zincke $\mathrm{H}$. The Mayo Clinic experience with surgical management, complications and outcome for patients with renal cell carcinoma and venous tumour thrombus. BJU Int 2004; 94: 33-41. [CrossRef]

10. Guo HF, Song Y, Na YQ. Value of abdominal ultrasound scan, CT and MRI for diagnosing inferior vena cava tumour thrombus in renal cell carcinoma. Chin Med J (Engl) 2009; 122: 2299-302.

11. Oto A, Herts BR, Remer EM, Novick AC. Inferior vena cava tumor thrombus in renal cell carcinoma: staging by MR imaging and impact on surgical treatment. AJR Am Roentgenol 1998; 171: 1619-24. [CrossRef]

12. Lawindy SM, Kurian T, Kim T, Mangar D, Armstrong PA, Alsina AE, et al. Important surgical considerations in the management of renal cell carcinoma (RCC) with inferior vena cava (IVC) tumour thrombus. BJU Int 2012; 1464-10.

13. Goldfarb DA, Novick AC, Lorig R, Bretan PN, Montie JE, Pontes JE, et al. Magnetic resonance imaging for assessment of vena caval tumor thrombi: a comparative study with venacavography and computerized tomography scanning. J Urol 1990; 144: 1100-3.

14. Kallman DA, King BF, Hattery RR, Charboneau JW, Ehman RL, Guthman DA, et al. Renal vein and inferior vena cava tumor thrombus in renal cell carcinoma: CT, US, MRI, and venacavography. J Compuz Assist Tomogr 1992; 16: 240-7. [CrossRef]

15. Hallscheidt PJ, Bock M, Riedasch G, Zuna I, Schoenberg SO, Autschbach $F$, et al. Diagnostic accuracy of staging renal cell carcinomas using multidetector-row computed tomography and magnetic reso- nance imaging: a prospective study with histopathologic correlation. J Comput Assist Tomogr 2004; 28: 333-9. [CrossRef]

16. Nazim SM, Ather MH, Hafeez K, Salam B. Accuracy of multidetector CT scans in staging of renal carcinoma. Int J Surg 2011; 9: 86-90. [CrossRef]

17. Karnes RJ, Blute ML. Surgery Insight: management of renal cell carcinoma with associated inferior vena cava thrombus. Nat Clin Pract Urol 2008; 5: 329-39.

18. Mizoguchi T, Koide Y, Ohara M, Okumura F. Multiplane transesophageal echocardiographic guidance during resection of renal cell carcinoma extending into the inferior vena cava. Anesth Analg 1995; 81 : 1102-5. [CrossRef]

19. Schwartz MJ, Smith EB, Trost DW, Vaughan ED Jr. Renal artery embolization: clinical indications and experience from over 100 cases. BJU Int 2007; 99: 881-6. [CrossRef]

20. Wotkowicz C, Libertino JA, Sorcini A, Mourtzinos A. Management of renal cell carcinoma with vena cava and atrial thrombus: minimal access vs median sternotomy with circulatory arrest. BJU Int 2006; 98: 289-97. [CrossRef]

21. Browning AJ, Eardley I, Joyce AD, Minhas S, Bellamy MC. Percutaneous veno-venous bypass in surgery for renal cell carcinoma with associated vena caval tumour thrombus. BJU Int 1999; 83: 850-2. [CrossRef]

22. Varkarakis IM, Bhayani $\mathrm{SB}$, Allaf ME, Inagaki $\mathrm{T}$, Gonzalgo ML, Jarrett TW. Laparoscopic-assisted nephrectomy with inferior vena cava tumor thrombectomy: preliminary results. Urology 2004; 64: 925-9. [CrossRef]

23. Gonzalez J, Angulo J, Ciancio G. Surgical management of renal cell cancer with tumor thrombus through an exclusive transabdominal approach. Arch Esp Urol 2011; 64: 297-309.

24. Parekh DJ, Cookson MS, Chapman W, Harrell F Jr, Wells N, Chang $\mathrm{SS}$, et al. Renal cell carcinoma with renal vein and inferoir vena caval involvement: cliniciopathological features, surgical techniques and outcomes. J Urol 2005; 173: 1897-902. [CrossRef]

25. Ciancio G, Soloway MS. Renal cell carcinoma with tumor thrombus extending above the diaphragm: avoiding cardiopulmonary bypass. Urology 2005; 66: 266-70. [CrossRef]

26. Wang GJ, Carpenter JP, Fairman RM, Jackson BM, Malkowicz B, Van Arsdalen KN, Woo EY. Single-center experience of caval thrombectomy in patients with renal cell carcinoma with tumorthrombus extension into the inferior vena cava. Vasc Endovascular Surg 2008; 42: 335-40. [CrossRef] 